\title{
KEBIJAKAN PENINGKATAN MUTU PENDIDIKAN BERBASIS AL- QUR'AN DI TK DARUL QUR'AN AL-KARIM KARANGTENGAH BATURRADEN BANYUMAS TAHUN 2016-2017
}

\author{
Safrudin Aziz \\ IAIN Purwokerto \\ Email : azieez@gmail.com
}

\begin{abstract}
ABSTRAK
Penelitian ini bertujuan mengetahui gambaran secara utuh dan menyeluruh tentang implementasi kebijakan peningkatan mutu pendidikan berbasis al-Qur'an di TK Darul Qur'an al-Karim Karangtengah Banyumas tahun 2016-2017 serta berbagai aspek kekuatan, kelemahan, peluang, ancaman atau tantangan terhadap implementasi kebijakan dirumuskan dalam tulisan ini. Penelitian ini menggunakan pendekatan kualitatif deskriptif. Teknik pengumpulan data menggunakan wawancara mendalam, pengamatan peran, observasi partisipasi serta dokumentasi. Analisis data dalam penelitian ini menggunakan beberapa tahap yakni : reduksi data, display data, serta conclusion drawing dan verification. Hasil penelitian ini memuat dua poin inti yakni: terungkapnya tujuh jenis kebijakan meliputi: kebijakan berbasis shalat sunnah, kebijakan berbasis tahfidz al-qur'an, kebijakan berbasis jum'at language, kebijakan berbasis kreativitas guru, kebijakan berbasis parenting qur'ani, kebijakan berbasis infak, kebijakan pembiayaan berbasis low cost. Selanjutnya kebijakan tersebut di analisis melalui SWOT untuk mengetahui sisi kekuatan, kelemahan, ancaman serta solusi terhadap pelaksanaan kebijakan tersebut.
\end{abstract}

Kata kunci: Kebijakan pendidikan; Analisis SWOT; Taman Kanak-Kanak.

\begin{abstract}
This study aims to determine the overall picture and comprehensive about the implementation of education quality improvement policies based on al quran in TK Darul Qur'an al Karim Karang tengah Banyumas 2016-2017, as well as various aspects of strengths, weaknesses, opportunities, threats or challenges to policy implementation formulated in this paper. This research uses descriptive qualitative approach. Data collection techniques used in-depth interviews, role observation, participatory observation and documentation. Data analisys in this research using several stages namely: data reduction, display data, and conclusion drawing and verification. The results of this study contain two core points namely: the disclosure of seven types of policies include: Sunna-based prayer policy, based tahfidz Al Qur'an, Furthermore, the policy is analyzed through SWOT to know the strength, weakness, threat and solution to the implementation of the policy.
\end{abstract}

Keywoard : Education of Policy; SWOT analisys; Kindergarten.

\section{PENDAHULUAN}

Para ahli sepakat bahwa terkelolanya lembaga pendidikan Taman Kanak-Kanak (TK) secara berkualitas turut menentukan nasib masa depan suatu bangsa. Tanpa adanya penyiapan lembaga pendidikan Taman Kanak-Kanak secara berkualitas, maka masa depan generasi bangsa akan mengalami kehancuran secara intelektualitas, moralitas, dan spiritualitas. Bahkan dampak kritis yang sangat mungkin terjadi adalah generasi penerus bangsa kian mudah terjangkit penyakit kronis secara lahiriah maupun batiniah. Mereka mudah terpengaruh, terjajah, tersusupi sekaligus terkontaminasi oleh asupan paham yang menghancurkan jati dirinya sebagai manusia Indonesia yang bertaqwa. 
Dalam posisi yang sama, lembaga pendidikan Taman KanakKanak yang tidak disiapkan serta tidak dikelola secara serius menjadi bumerang dalam melahirkan manusia unggulan yang mampu melahirkan ideide kreatif, kritis, progresif, serta berjiwa pembaharu. Padahal anak usia dini diyakini sebagai golden age (memasuki masa keemasan) dalam pembentukan dan pertumbuhan kecerdasannya. Untuk itu mempersiapkan lembaga pendidikan Taman Kanak-Kanak secara profesional, bermutu dan berkualitas, menjadi satu terobosan penting dalam mempersiapkan masa depan anak yang berkualitas serta unggul secara jasmani dan ruhani.

Mempersiapkan lembaga pendidikan Taman Kanak-Kanak yang bermutu ditentukan oleh berbagai faktor penting. Salah satunya adalah adanya kebijakan kepala Taman Kanak-Kanak terhadap peningkatan mutu pendidikan. Kebijakan sebagaimana diartikan para ahli sebagai arah tindakan yang mempunyai maksud yang ditetapkan oleh seorang actor atau sejumlah actor dalam mengatasi suatu persoalan (Anderson 1969, 4) menjadi suatu hal yang harus diupayakan. Sebab kebijakan merupakan sesuatu yang lahir dari masalah, yakni adanya kesenjangan antara keadaan dan harapan (Djohar 2008, 3). Dalam konteks tersebut, memberikan pemahaman bahwa kebijakan diperlukan sebagai bentuk komitmen dan keseriusan sebuah lembaga dalam mengembangkan sekaligus mengatasi berbagai tantangan, problem ataupun hambatan di sebuah lembaga.

Salah satu bentuk kebijakan yang harus mendapat perhatian serius dari sebuah lembaga pendidikan Taman
Kanak-Kanak diantaranya pengembangan mutu pendidikan berbasis al-Qur'an. Mutu secara khusus dimaknai sebagai suatu kondisi dinamis yang berhubungan dengan produk, jasa, manusia, proses, dan lingkungan yang memenuhi atau melebihi harapan (Goetsch \& Davis 2003, 4), sehingga pengembangan mutu pendidikan berbasis al-Qur'an dipahami sebagai suatu bentuk kebijakan yang dilakukan oleh lembaga pendidikan Taman KanakKanak untuk menanamkan nilai-nilai intelektual, emosional, spiritual serta sosial secara qur'ani sesuai dengan tingkat usia dan kemampuannya.

Dari uraian tersebut, kebijakan dalam meningkatkan mutu pendidikan berbasis al-Qur'an di lembaga Taman Kanak-Kanak setidaknya dapat dipahami sebagai tindakan konkret dan terencana yang bertujuan mencapai kemajuan sekolah serta menumbuh kembangkan kecerdasan anak melalui strategi khusus, yakni bersifat academic oriented maupun pembekalan life skills berdasarkan nilai-nilai ajaran al-Qur'an. Untuk mencapai target tersebut, kebijakan pengembangan mutu pendidikan berbasis nilai-nilai ajaran al-Qur'an di Taman Kanak-Kanak harus bersifat active learning, fleksibel, original, berbasis produk, serta tidak mengesampingkan target capaian sesuai dengan kurikulum yang berlaku. Adapun salah satu lembaga pendidikan Taman Kanak-Kanak yang memiliki kebijakan peningkatan mutu pendidikan berbasis al-Qur'an adalah TK Darul Qur'an al-Karim Karangtengah Baturraden Banyumas.

TK Darul Qur'an al-Karim Karangtengah Baturraden Banyumas yang memiliki visi di tahun 2025 menjadi pusat pendidikan anak usia 
dini berbasis al-Qur'an terdepan di wilayah Kabupaten Banjarnegara, Purbalingga, Banyumas, Cilacap, Kebumen (Barlingmascakeb), merupakan salah satu lembaga pendidikan berbentuk Taman Kanakkanak di bawah Yayasan Pondok Pesantren Modern Darul Qur'an alKarim Karangtengah Baturraden Banyumas. Secara operasional, TK ini sudah berdiri semenjak tahun 2015 . Akan tetapi secara legal ijin operasional TK Darul Qur'an al-Karim baru turun tepatnya 8 Maret 2017 dengan terbitnya SK Kepala Dinas Pendidikan Kabupaten Banyumas Nomor: 421.1/125/2017.

Secara usia dan kelembagaan, TK Darul Qur'an al-Karim terbilang masih sangat muda serta memiliki struktur organisasi yang sederhana. TK ini di kelola oleh satu orang kepala, tujuh orang guru, satu staf administrasi, 70 siswa, serta Dewan Pembina yang berperan sebagai supporting dari yayasan Darul Qur'an al-Karim. Meskipun terbilang masih berusia muda, TK ini sudah menjadi favorit serta pilihan pertama masyarakat Karangtengah Baturraden Banyumas. Terbukti TK Darul Qur'an al-Karim pada setiap tahun ajaran baru kerap menolak puluhan calon siswa baru.

Menumpuknya jumlah peminat untuk lebih memilih TK Darul Qur'an al-Karim bagi masyarakat sekitar dilatarbelakangi oleh berbagai faktor diantaranya TK Darul Qur'an al-Karim memiliki kekhasan kebijakan peningkatan mutu pendidikan berbasis al-Qur'an yang tidak dikembangkan oleh TK yang lain. Kekhasan kebijakan tersebut merupakan satu bentuk komitmen kepala sekolah serta pihak yayasan yang dilakukan secara totalitas, terukur serta memiliki indikator yang jelas dari setiap kebijakan program yang ditetapkan. Implementasi kebijakan tersebut juga dilakukan melalui perencanaan secara matang, kontrol mutu, progress program, evaluasi serta perbaikan yang dilakukan secara terus menerus. Semua itu menjadi kebijakan utuh dari kepala sekolah serta pendampingan dari unsur terkait yakni pihak yayasan.

Sehubungan dengan uraian di atas, penelitian ini secara konkret bertujuan memberikan gambaran yang utuh dan menyeluruh tentang implementasi kebijakan peningkatan mutu pendidikan berbasis al-Qur'an di TK Darul Qur'an al-Karim Karangtengah Banyumas tahun 20162017 serta berbagai aspek kekuatan, hambatan, peluang serta solusi dalam menghadapi tantangan dan problematika yang ada.

\section{METODE PENELITIAN}

Penelitian yang mengkaji tentang implementasi kebijakan mutu pendidikan berbasis al-Qur'an di TK Darul Qur'an al-Karim ini berbentuk penelitian lapangan (field research) dengan menggunakan pendekatan kualitatif deskriptif (Arikunto 2014, 3). Adapun teknik pengumpulan data yang dilakukan dalam penelitian ini menggunakan indept interview atau wawancara mendalam terhadap kepala TK, guru, pengurus yayasan, serta wali siswa. Selain wawancara mendalam, pengumpulan data juga dilakukan melalui pengamatan peran serta participant observation, dan dokumentasi. Setelah data terkumpul, dilakukan analisis dengan langkahlangkah sebagai berikut:

Pertama, reduksi data (reduction data) yakni merangkum, memilih data yang pokok dan penting, membuat kategorisasi, dicari tema dan polanya, serta membuang yang tidak perlu (Sugiyono 2013, 339). Dengan 
demikian data yang telah direduksi akan memberikan gambaran yang lebih jelas, dan mempermudah peneliti untuk melakukan pengumpulan data selanjutnya, dan mencarinya bila diperlukan. Kedua penyajian data (display data). Penyajian data bisa dilakukan dalam bentuk uraian singkat, bagan, hubungan antar kategori, flowchart, dan sejenisnya. Adapun dalam menyajikan data dilakukan dengan teks yang bersifat naratif. Ketiga, conclusion drawing dan verification yakni penarikan kesimpulan dan verifikasi.

\section{HASIL DAN PEMBAHASAN 1. Proses Lahirnya Kebijakan}

Lembaga pendidikan yang berkualitas secara teoritik maupun praktik harus memiliki kebijakan rancangan program peningkatan mutu yang jelas, dilakukan secara terpadu, terarah, serta memiliki indikator yang terukur. Michael Howlet dan M. Ramesh menetapkan kebijakan peningkatan mutu pendidikan setidaknya dilakukan melalui lima langkah strategis yakni: pertama, penyusunan agenda dimaksudkan agar suatu masalah mendapat perhatian. Kedua, formulasi kebijakan yaitu proses perumusan pilihan-pilihan kebijakan. Ketiga, pembuatan tindakan, untuk memilih melakukan tindakan atau tidak melakukan tindakan. Keempat, implementasi kebijakan, melaksanakan kebijakan agar mencapai hasil. Kelima, evaluasi kebijakan; memonitor atau menilai hasil atau kinerja kebijakan(Howlet \& Ramesh, 11).

Selaras dengan pendapat di atas, Anderson juga mengemukakan, penetapan proses kebijakan setidaknya memerlukan beberapa langkah diantaranya: menentukan formulasi masalah, menentukan formulasi kebijakan, menentukan jenis kebijakan yang akan dilakukan, serta implementasi dan evaluasi kebijakan (Anderson 1979, 23-24). Sementara Dunn, menggambarkan proses analisa kebijakan publik idealnya dilakukan melalui langkah-langkah sebagai berikut: a) penyusunan agenda. b) formulasi kebijakan. c) Adopsi kebijakan. d) implementasi kebijakan. e) evaluasi kebijakan (Dunn 1994, 17). Mencermati teori di atas, penentuan agenda suatu masalah menjadi salah satu aspek utama lahirnya sebuah kebijakan. Penentuan agenda dilakukan TK Darul Qur'an alKarim melalui observasi secara langsung terhadap proses pembelajaran di lapangan, melakukan pencatatan, dokumentasi, wawancara terhadap pihak-pihak yang terlibat serta penyebab munculnya masalah, sekaligus melakukan identifikasi secara prioritas.

Hasil identifikasi tersebut selanjutnya dirapatkan secara rutin diakhir pekan dengan dewan guru. Rapat akhir pekan tentunya menghasilkan berbagai gagasan, solusi yang bersifat sementara. Hasil rapat akhir pekan terdokumentasi dalam notulensi rapat sekolah, adapun kumpulan agenda yang dihasilkan dalam rapat akhir pekan dibahas secara transparan dalam rapat bulanan bersama pihak yayasan. Hasil rapat akhir bulan secara pasti melahirkan formulasi kebijakan yang bersumber dari pengurus yayasan bersama kepala TK.

Dari hasil rapat itulah, kepala TK menetapkan berbagai kebijakan dalam meningkatkan mutu pendidikan berbasis al-Qur'an. Penetapan kebijakan ini disosialisasikan kepada guru sebagai pihak pelaksana 
implementasi kebijakan di lapangan. Penetapan kebijakan ini dilakukan secara tertulis dan terkendali di bawah pengawasan kepala TK dan yayasan. Pasca tahap penetapan, implementasi kebijakan dilakukan secara terstruktur. Artinya implementasi kebijakan dilakukan guru sesuai dengan kompetensi dan bidangnya masingmasing. Meskipun demikian, dalam mengimplementasikan kebijakan seluruh guru saling bahu membahu, saling memotivasi, saling mengisi kekurangan masing-masing, sekaligus memperkuat koordinasi, kerjasama serta komitmen dalam mensukseskan kebijakan tersebut.

Tahap paling akhir adalah evaluasi kebijakan. Tahap ini secara realistis dilakukan oleh guru bersama dengan kepala sekolah setiap akhir pekan. Evaluasi implementasi kebijakan dilakukan secara kualitatif maupun kuantitatif dengan menghitung prosentase peningkatan mutu pendidikan melalui peningkatan kemampuan siswa serta masukan dari wali siswa terhadap pelaksanaan program pembelajaran.

Dari uraian di atas, dapat disimpulkan perumusan kebijakan kepala TK Darul Qur'an al-Karim Karangtengah Baturraden mengalami proses yang cukup panjang. Proses ini setidaknya mengadopsi gagasannya Anderson yakni diawali dengan menentukan formulasi masalah, kebijakan, menentukan jenis kebijakan yang akan dilakukan, serta implementasi dan evaluasi kebijakan.

\section{Kebijakan Peningkatan Mutu Pendidikan Berbasis al-Qur'an}

Kebijakan peningkatan mutu pendidikan berbasis al-Qur'an di TK Darul Qur'an al-Karim Karangtengah Baturraden Banyumas secara substansial terdiri atas beberapa program kegiatan diantaranya:

\section{a. Kebijakan Berbasis Shalat Sunnah}

Kebijakan berbasis shalat sunah di TK Darul Qur'an al-Karim dilakukan dalam program shalat sunnah Dhuha berjama'ah. Program ini dilakukan setiap hari sebagai awal dimulainya proses pembelajaran. Program ini bersifat wajib bagi seluruh peserta didik melalui pendampingan langsung dari guru, secara tersirat program ini menjadi satu bentuk pembiasaan ibadah sunah bagi siswa sekaligus guru dan orang tua. Program shalat dhuha berjama'ah tentunya melekat dengan ritual do'a yang diawali dengan pembacaan dan hafalan Asmaul husna yang versi notasinya gubahan dari lagu "Balonku Ada Lima" secara bersama-sama. Tujuan dari program ini dimaksudkan untuk menghantarkan peserta didik memiliki kecerdasan secara spiritual. Sehingga pengembangan kecerdasan spiritual menjadi dasar bagi pembentukan kecerdasan intelektual yang dilakukan melalui proses pembelajaran, ataupun kecerdasan sosial yang dilakukan melalui proses interaksi dengan kawan-kawan, guru dan lingkungannya.

Kecerdasan spiritual menjadi satu kebutuhan pokok yang tidak bisa dikesampingkan. Sebab lembaga pendidikan semenjak Taman Kanak-Kanak hingga perguruan tinggi mengalami krisis spiritual yang sudah semakin parah. Padahal ketika kecerdasan intelektual serta kebutuhan material tidak mampu menjadi alternatif dalam memperbaiki kebobrokan karakter seseorang. Langkah paling akhir adalah mengembalikan segala 
urusan kepada Sang Pencipta. Sebab perubahan karakter lebih didominasi oleh peran qalbu. Dan Tuhan sang penciptalah dzat yang mampu merubah dan membolak-balikan hati setiap manusia. Sehingga tiga rangkaian kegiatan yakni shalat dhuha, ritualitas do'a dan membaca Asmaul Husna secara bersama-sama menjadi kebijakan yang bersifat alternatif dalam memperbaiki serta membangun kepekaan, ketajaman dan kecerdasan spiritual anak.

Adapun indikator dari
kebijakan ini diantaranya:
terbentuknya suasana kebersamaan antara guru, peserta didik dan orang tua, menurunnya tingkat kenakalan anak, mudah diterimanya berbagai pengetahuan bagi setiap anak, lahirnya kesadaran dan kepekaan anak untuk saling membantu, berbagi dan bekerja sama, serta menjamin kesucian hati setiap peserta didik dan guru sehingga proses pembelajaran tidak sebatas disampaikan dari otak ke otak. Namun transfer of knowledge and values melintasi batas ruhaniah.

Dengan demikian proses peningkatan mutu pendidikan tidak sebatas dilakukan melalui upaya pemenuhan kebutuhan intelektual, moral ataupun material. Akan tetapi pemenuhan kebutuhan spiritual menjadi satu-satunya landasan utama dalam meningkatkan mutu pendidikan di Taman Kanak-Kanak. Sebab melalui kebersihan hati, berbagai informasi pengetahuan yang bersifat lahiriah maupun batiniah dapat tersalurkan dan diterima dengan sempurna.

\section{b. Kebijakan Berbasis Tahfidz al- Qur'an}

Istilah tahfidz al-Qur'an berasal dari dua kata yaitu hifdz dan al-Qur'an. Kata hifdz yang asal katanya dari kata hafidza-yahfadzuhifdzan berarti menjaga, memelihara, melindungi. Jika kata ini disambungkan dengan kata aldars mengandung arti menghafal (Munawwir 1997, 279), sementara kata menghafal dapat dipahami sebagai usaha meresapkan ke dalam pikiran agar selalu ingat (KBBI 2005, 381). Dari kedua istilah di atas, tahfidzul Qur'an secara sederhana dapat diartikan sebagai program menghafal ayat-ayat yang terdapat dalam mushaf al-Qur'an berdasarkan nomor surat yang ada pada mushaf bukan didasarkan pada urutan turunnya ayat al-Qur'an. Sementara hafidz menegaskan menghafal al-Qur'an berarti memindahkan al-Qur'an dari tulisan ke dalam dada si penghafalnya (AlHafidz 1995, 2), dengan tujuan menjaga kemurniaan al-Qur'an, memperoleh kedudukan yang mulia di dunia dan akhirat, serta menanamkan akhlak al-Qur'an ke dalam hati anak.

Program tahfidz juz 30 bagi setiap anak didik sebagai kebijakan unggulan kepala sekolah menjadi salah satu terobosan mensukseskan visi TK Darul Qur'an al-Karim. Pembelajaran tahfidz al-Qur'an secara khusus menjadi tanggung jawab guru bidang al-Qur'an. Adapun spesifikasi guru tahfidz adalah berpendidikan S1 serta memiliki kompetensi hafalan alQur'an 30 juz.

Pembelajaran tahfidz bagi anak dilakukan setiap hari yang dilekatkan dengan kegiatan do'a serta shalat dhuha berjama'ah. Pembelajaran tahfidz bagi anak di TK Darul Qur'an al-Karim menggunakan Metode 
Master. Metode ini mengadopsi penemuan Bobby Herwibowo, seorang ahli yang berasal dari Yayasan Askar Kauny. Metode Master lebih mengoptimalkan gerak tangan sebagai fungsi kinestetik, serta memfokuskan mata dan telinga sebagai audio dan visual. Sehingga semua anak dengan multi talenta dapat melakukannya.

Pembelajaran tahfidz diawali dari awal juz 30 hingga surat terakhir dalam al-Qur'an. Pada awalnya pembelajaran tahfidz melalui metode Master ini di rasa lama dalam mencapai titik keberhasilan. Namun metode Master mampu membuat anak menjadi senang, riang, sekaligus aktif baik melalui gerak tangan maupun gerak bibir. Dalam konteks pembelajaran bagi anak usia dini, prinsip active learning harus diperhatikan. Sebab anak usia dini mulai tumbuh kreativitasnya. Sehingga mereka memiliki rasa ingin tahu terhadap apapun yang ada disekitarnya.

Melalui metode Master, target visi serta kebijakan kepala TK Darul Qur'an al-Karim dalam meningkatkan mutu pendidikan berbasis al-Qur'an dapat tercapai secara optimal. Indikator yang tampak diantaranya anak berani tampil melantunkan bacaan surat-surat panjang dalam $J u z$ 'Amma secara bersama-sama baik dalam perlombaan, pertunjukan ataupun menyambut acara ketika hadir serombongan tamu yang berkunjung baik berskala nasional ataupun internasional. Selain itu, metode Master menuntut semua guru ikut menghafal surat-surat dalam alQur'an khususnya yang terdapat dalam juz 30.

Adapun indikator dari kebijakan ini anak usia dini mampu mengenal, mempelajari serta menghafal ayat- ayat al-Quran dengan baik khususnya yang terdapat dalam juz terakhir dari mushaf al-Qur'an.

\section{c. Kebijakan Berbasis Jum'at Language}

Kebijakan ini menjadi salah satu program yang harus dilakukan oleh guru kepada peserta didik di TK Darul Qur'an al-Karim. Meskipun bersifat mengenalkan serta menanamkan hafalan kosakata bahasa Arab dan Inggris secara sederhana, program ini menjadi alternatif refreshing anak melalui pengenalan kosakata asing ditelinganya, khususnya dalam memperkenalkan kosakata bahasa Arab, tentunya menjadi bagian pendukung pencapaian visi TK yakni menjadi pusat lembaga pendidikan anak usia dini berbasis al-Qur'an. Sebab penguasaan bahasa Arab yang baik menjadi satu-satunya bekal menguasai alQur'an, sedangkan memperkenalkan kosakata bahasa Inggris secara sederhana menjadi bekal anak terbiasa mendengarkan, mengucapkan, bahkan menghafal vocabulary yang ada disekitar anak. Penguasaan bahasa Inggris secara sempurna tentu memiliki tujuan vital, yakni seseorang mampu menguasai informasi dunia. Bahkan kemukjizatan al-Qur'an tidak jarang ditemukan oleh orang asing yang dikemas dalam bahasa Inggris.

Melalui perihal itulah, Jum 'atLanguage menjadi salah satu kebijakan unggulan di TK Darul Qur'an al-Karim. Program pembelajaran dalam kemasan Jum'at-Language tentu dilakukan secara tematik sesuai dengan tingkat kemampuan anak. Evaluasi kemampuan anak terhadap penguasaan bahasa asing melalui 
kebijakan tersebut tentu dilakukan secara terukur. Adapun indikator kebijakan Jum'at-Language adalah guru dan peserta didik memiliki kemampuan penguasaan bahasa Inggris dan Arab secara lebih baik, peserta didik memiliki tingkat kepercayaan diri untuk tampil di depan umum khususnya dalam mengucapkan kata-kata asing, peserta didik senantiasa merasa bahagia karena proses pembelajaran dikemas secara menyenangkan.

Proses

pembelajaran

menyenangkan dalam bidang bahasa Arab dan Inggris dalam program Jum'at Language di TK Darul Qur'an al-Karim umumnya mempergunakan lagu anak-anak. Beberapa modifikasi lagu yang diciptakan diantaranya sebagai berikut:

1) Gubahan Lagu dari Notasi Versi Kebunku

$T V$-television

Radio-radio

Koran-newspaper

Majalah-magazine

Telepon-telephone

Internet-internet

Telpon genggamhandhpone

Surat itu-letter

2) Gubahan Lagu dari Notasi Versi Potong Bebek Angsa

Jacket itu jaket

Shoes itu sepatu

Cloths adalah baju

Ball adalah bola

Umbrella payung

Bag adalah tas

Mattress matras

Medicine itu obat

Hal itu topi

Raincoat jas hujan

Drink minuman dan food itu makanan

3) Gubahan Lagu dari Notasi Versi Pelangi-Pelangi

Berbahasa Arab Ra'sun itu kepala

Aainun itu mata

Udunun itu telinga

Syafatun itu bibir

Wajhun itu wajah

Unufun itu hidung

Yadun itu tangan

Anfu itu hidung

Rijlun itu kaki

Dari uraian di atas dapat disimpulkan bahwa kebijakan TK Darul Qur'an al-Karim Karangtengah Baturraden sudah mampu menerawang kebutuhan peserta didik secara lintas batas. Artinya kebijakan Jum'at-Language bertujuan mengantarkan peserta didik untuk menguasai al-Qur'an sebagai bekal keselamatan akhirat. Sementara kebutuhan bahasa Inggris menjadi alternatif solusi peserta didik ke depan mampu berinteraksi, menimba pengetahuan dan pengalaman secara global. Sebab penguasaan bahasa internasional yakni Arab dan Inggris selain menjadi kebutuhan sekaligus menjadi tuntutan bagi seseorang dalam menjelajah informasi ataupun ilmu pengetahuan secara mendunia.

\section{d. Kebijakan Berbasis Kreativitas Guru}

Kreativitas mengajar setiap guru menjadi satu bentuk kebijakan kepala TK Darul Qur'an al-Karim. Kreativitas ini dikembangkan melalui pertemuan rutin yang terkemas dalam rapat akhir pekan antara guru dengan kepala TK, serta pengadaan workshop atau pelatihan 
secara intensif khususnya terkait dengan pengembangan kurikulum dua ribu tiga belas, pengembangan bahan ajar, pengembangan metode dan strategi, pengembangan program pembelajaran pendamping atau ciri khas seperti materi ke-Islaman dan ke al-Qur'anan.

Secara teknis, pengembangan kreativitas guru tentunya dilakukan berdampingan dengan penyusunan Rencana Kegiatan Mingguan (RKM). Dalam setiap penyusunan RKM, kepala sekolah langsung merekomendasikan seluruh guru untuk membuat modifikasi lagu-lagu, tepuk ataupun berbagai gerakan anggota badan yang sesuai dengan materi yang akan diajarkan. Semua bentuk modifikasi tersebut dipahami sebagai media untuk memudahkan proses belajar anak.

Beberapa modifikasi lagu dan tepuk hasil kreativitas guru TK Darul Qur'an al-Karim diantaranya sebagai berikut:

1) Notasi Lagu versi Menanam Jagung

Montain gunung

Fields itu sawah

Soy itu kedelai

Vegetable sayur

Chili itu cabe

Tomato tomat

Beans kacang-kacangan

Tress $5 x$ pohon-pohon

Beach itu pantai

Sea itu laut.

2) Notasi Lagu Versi GundulGundul Pacul

Negara itu country

Bendera itu flag

Pemerintah itu

government

Presiden president

Wakil presiden itu vice president
Suku ethnic

Kepulauan archipelago

president

Wakil presiden itu vice

Suku ethnic

Kepulauan archipelago

3) Notasi Lagu dan Tepuk Versi Kalau Kau Suka Hati Tepuk Tangan

Kalau kau suka nasi tepuk tangan (prokprok-prok)

Kalau kau suka daging tepuk tangan (prokprok-prok)

Kalau kau suka sayur, kalau kau suka buah, kalau kau suka susu tepuk tangan (prokprok-prok).

Kalau kau suka semua tepuk tangan (prokprok-prok)

Ayolah kawan jangan pilih makanan (prokprok-prok)

Sukalah semuanya nasi, daging, sayur, buah Lebih sehat di tambah dengan susu (prok-prokprok).

Beberapa modifikasi lagu dan tepuk hasil kreativitas guru secara teknis dipersiapkan secara bersamasama dalam rapat mingguan. Penciptaan berbagai lagu, modifikasi lagu atau dan tepuk tentunya di sesuaikan dengan tema pembelajaran. Dengan demikian penyusunan lagu ataupun tepuk menjadi bagian melekat dalam penyusunan Rencana Kegiatan Mingguan (RKM). Selanjutnya, semua RKM serta berbagai lagu dan tepuk menjadi karya original guru 
untuk didokumentasikan bahkan dipublikasikan secara meluas.

Hasil kreativitas guru rencananya akan di buatkan Hak Atas Kekayaan Intelektual (HAKI) dari Kementerian Hukum dan Hak Asasi Manusia melalui Dirjen Hak Kekayaan Intelektual. Semua itu dilakukan selain sebagai motivasi bagi guru, karya yang di-HAKI-kan bermanfaat menambah nilai plus bagi lembaga serta diakuinya karya tersebut secara nasional. Dengan demikian kebijakan berbasis pengembangan kreativitas guru di TK Darul Qur'an al-Karim secara substantif dimaksudkan untuk mewujudkan pelaksanaan pembelajaran secara lebih berkualitas, menghasilkan produk kreatif, membiasakan guru tegar dalam menghadapi tantangan, menaikan citra lembaga secara nasional. Semua itu tidak lain dimaksudkan untuk mendukung realisasi visi lembaga menjadi lembaga pendidikan anak usia dini berbasis al-Qur'an terdepan di wilayah Barlingmascakeb.

\section{e. Kebijakan Berbasis Parenting Qur'ani}

Kata parenting Secara bahasa Berasal dari bahasa Inggris, Parent yang berarti Orang tua (Echols \& Hasan 2005, 418), sedangkan dalam kamus Oxford, parenting adalah the process of caring for your child or children (Homby 2010, 1067). Sementara definisi parenting yang mudah dipahami adalah suatu perilaku yang pada dasarnya mempunyai kata-kata kunci yaitu hangat, sensitif, penuh penerimaan, bersifat resiprokal, ada pengertian dan respon yang tepat pada kebutuhan anak (Khotimatun 2009,
88-100). Arismantoro memberikan pengertian parenting sebagai segala sesuatu yang berurusan dengan tugas-tugas orang tua dalam mendidik dan membesarkan anak (Arismantoro 2008, 39).

Melihat berbagai definisi di atas, parenting secara sederhana dapat dipahami sebagai upaya orang tua yang dilakukan secara terstruktur untuk merawat, mendidik, membimbing, membantu, melatih dan memimpin anak melalui langkah, pendekatan, strategi dan metode tertentu dengan tujuan agar anak mampu melakukan perubahan dari sisi kecerdasan, sikap dan karakternya. Apabila dikontektualisasikan dengan nilainilai al-Qur'an, maka seluruh kegiatan parenting harus didasarkan pada nilai-nilai yang terdapat dalam al-Qur'an baik secara tersurat maupun tersirat.

Parenting qur'ani sejak tahun 2015/2016 menjadi salah satu kebijakan unggulan TK Darul Qur'an al-Karim. Kegiatan ini disatukan dengan program pemberdayaan perempuan khususnya bagi wali siswa TK. Tujuan kebijakan ini selain sebagai salah satu misi TK yakni mensosialisasikan konsep Qur'anic Parenting kepada masyarakat, setiap wali siswa diharapkan menguasai serta mampu mengimplementasikan Qur'anic Parenting kepada putra-putrinya dalam keluarga. Melalui langkah ini, proses peningkatan mutu pendidikan berbasis al-Qur'an tidak sebatas dilakukan dan menjadi tanggung jawab sekolah, namun pendidikan dalam keluarga turut men-support pelaksanaan implementasi kebijakan sekolah. Sehingga aktualisasi pendidikan dalam sekolah memiliki 
keselarasan dengan pendidikan yang diselenggarakan dalam keluarga.

Materi Parenting Qur'ani yang diselenggarakan TK Darul Qur'an alKarim pada hakikatnya lebih menekankan aspek penanaman penguatan akidah yang lurus bagi anak, penanaman akhlak yang mulia, sekaligus bentuk-bentuk parenting berbasis multi aspek yang memuat penguatan intelektual, sosial, mental, spiritual, emosional. Kegiatan parenting Qur'ani selain melibatkan guru, kepala sekolah, serta pembina yayasan. Penguatan program ini juga dilakukan melalui kerja sama pemateri parenting dari Rumah Kreatif Wadas Kelir (RKWK) Karanglesem Purwokerto, Politeknik Kesehatan Lingkungan Cabang Semarang di Purwokerto yang membidangi parenting kesehatan lingkungan, serta Badan Nasional Narkotika (BNN) yang membidangi masalah Napza.

Parenting qur'ani pada bidang penguatan aqidah pada intinya memuata tentang bagaimana mengajarkan bahkan menanamkan nilai-nilai tauhid kepada anak untuk selalu berhubungan harmonis dengan Allah SWT. Materi ini terdiri atas langkah-langkah: a) bagaimana memahamkan orang tua bahwa anak terlahir dalam keadaan fitrah, b) menanamkan tauhid dan aqidah yang benar kepada anak, c) mengajari anak mendirikan shalat, d) memotivasi anak agar gemar membaca al-Qur'an, e) memotivasi anak untuk gemar berdo'a, f) memotivasi anak untuk mencintai masjid, g) mengajari anak untuk menjaga aurat, h) mengajari anak untuk menjaga kebersihan tubuh, i), memotivasi anak agar rajin berpuasa, k) mengajari anak untuk selalu mencintai mahluk-mahluk ciptaanNya.

Selain menjalin hubungan secara harmonis dengan Sang Khalik, parenting qur'ani juga mengajarkan penanaman diri untuk selalu berhubungan secara harmonis dengan sesama manusia melalui pemberian pemahaman tentang bagaimana menanamkan sikap berbakti kepada kedua orang tua, taat dan hormat kepada guru, tips cara menumbuhkan jiwa sosial, simpati dan empati terhadap keadaan orang lain, mengajarkan anak berhati santun, sabar, lembut dan kasih sayang menjadi satu bentuk parenting Qur'ani di TK Darul Qur'an al-Karim.

Penanaman akhlak Qur'ani dalam parenting ini tentu dilakukan melalui berbagai langkah. Mulai dari tingkat pemahaman, penanaman, pembiasaan, sehingga terbentuk karakter. Proses ini mengadopsi pepatah bijak: Watch your thoughts, they become your words (perhatikan apa yang kita pikirkan, karena itu aka menjadi perkataan kita); watch your words, they become your beliefs (perhatikan apa yang menjadi perkataan kita karena akan menjadi sebuah keyakinan); watch your actions, they become your habbits (perhatikan tindakanmu, karena tindakan yang berulang-ulang akan menjadi kebiasaan); watch your habits, they become your character (perhatikan kebiasaan karena akan menjadi sikap dan karakter); watch your character, it becomes your destiny (perhatikan karakter karena itu akan menjadi masa depanmu).

Dari uraian di atas dapat disimpulkan parenting Qur'ani di TK Darul Qur'an al-Karim pada hakikatnya memuat indikator yang jelas dan terukur. Beberapa indikator 
pokok diantaranya orang tua mampu menjadi role mode dalam menanamkan aqidah, akhlak serta karakter yang kuat terhadap anakanaknya, yang dikemas melalui langkah-langkah strategis tanpa sering meninabobokan anak dengan segudang reward material atau punishment yang memberatkan. Selain itu, parenting Qur'ani menjadi salah satu kebijakan unggulan di TK Darul Qur'an alKarim dimaksudkan sebagai langkah mencapai keselarasan antara visi sekolah, program pendidikan disekolah, serta parenting dalam keluarga berbasis nilai-nilai Qur'ani. Perihal ini menjadi satu kekhasan kebijakan mandiri di TK Darul Qur'an al-Karim semenjak berdiri hingga saat ini.

\section{f. Kebijakan Berbasis Infak}

Kebijakan berbasis Jum'at berinfak menjadi salah satu kekhasan TK Darul Qur'an al-Karim dalam merealisasikan visi lembaganya. Kegiatan ini dilakukan setiap hari Jum'at oleh seluruh santri beserta guru. Program infak Jum'at secara khusus bertujuan untuk menanamkan tradisi berinfak bagi anak semenjak usia dini sekaligus memberikan pemahaman bahwa infak ataupun sedekah bermanfaat untuk menjaga keselamatan diri setiap anak dari berbagai keburukan. Berbagai bentuk keburukan dapat lahir dari diri sendiri, seperti: tidak kuatnya hafalan anak, buruknya akhlak anak, kurang menjunjung tinggi etika dan tata krama terhadap orang lain, bahkan hilangnya rasa empati, simpati serta tidak peduli terhadap sesama merupakan perihal yang harus dicarikan alternatif solusi perbaikannya. Sebagai upaya perbaikan tersebut salah satunya dilakukan melalui infak atau sedekah. Dengan mentradisikan infak secara rutin, diharapkan anak akan terhindar dari berbagai keburukan yang melekat dalam dirinya. Adapun hasil pengumpulan infak secara rutin akan disalurkan kepada pihak-pihak yang berhak menerima. Penyaluran infak tersebut dilakukan dalam bentuk home visit, pemberian santunan sosial, dan berbagai bentuk kegiatan sejenisnya.

Dari uraian di atas, dapat disimpulkan bahwa kebijakan TK Darul Qur'an al-Karim dalam meningkatkan mutu pendidikan berbasis al-Qur'an tampaknya sudah dilakukan secara realistis. Salah satunya kebijakan berbasis Jum'at berinfak, di samping berbagai bentuk kebijakan yang lainnya.

\section{g. Kebijakan Pembiayaan Berbasis Low Cost}

Kebijakan TK Darul Qur'an alKarim dalam hal pembiayaan pendidikan berbasis low cost. Perihal ini disebabkan tujuan TK Darul Qur'an bukan bersifat profit oriented, tetapi lebih menekankan pada aspek mensosialisasikan konsep Qur'anic Parenting sekaligus upaya melakukan transformasi masyarakat menuju masyarakat qur'ani. Sehingga lahirnya kebijakan pembiayaan berbasis low cost bukan berarti lembaga pendidikan ini tidak memerlukan anggaran operasional yang besar. Akan tetapi penganggaran operasional menjadi tanggung jawab yayasan di samping sumbangan dari masyarakat. Sebagai bukti, masyarakat sebatas diberikan beban SPP yang harus dibayarkan setiap bulannya sebesar Rp. 50.000.,(lima puluh ribu rupiah). Apabila dibandingkan dengan pembiyaan TK 
yang lain, biaya tersebut sangat jauh dari angka standar. Artinya rata-rata biaya pendidikan Taman Kanak-Kanak di wilayah kabupaten Banyumas umumnya mencapai kisaran $<$ Rp. 450.000,- (lebih dari empat ratus ribu rupiah). Dengan demikian, kebijakan pembiayaan berbasis low cost secara tersirat mengandung nilai-nilai ajaran al-Qur'an. Sehingga kebijakan tersebut menjadi pendukung tercapainya visi TK Darul Qur'an al-Karim.

\section{Analisis SWOT Kebijakan Berbasis Al-Qur'an di TK Darul Qur'an al-Karim}

Implementasi kebijakan peningkatan mutu pendidikan berbasis al-Qur'an di atas harus dilakukan analisis secara tepat. Sebab analisis kebijakan baik dalam tataran konsep maupun praktik menjadi alternatif penting dalam melihat situasi, kondisi serta optimalisasi ketercapaian kebijakan yang sudah dirumuskan. Adapun hasil analisis SWOT terhadap pelaksanaan kebijakan di TK Darul Qur'an al-Karim sebagai berikut:

a. Aspek kekuatan (strength).

Dilihat dari aspek kekuatan terdapat beberapa hal yang dapat di kemukakan diantaranya: pertama, secara riil TK Darul Qur'an alKarim sudah memiliki visi dan misi secara jelas dan terukur. Visi tersebut menjadi satu cita-cita besar yang harus diraih dalam jangka waktu tertentu. Kejelasan visi menjadikan pemangku kebijakan di TK Darul Qur'an alKarim merumuskan tujuh kebijakan dalam meningkatkan mutu pendidikan berbasis alQur'an.

Kedua, anggaran pengelolaan pendidikan di TK Darul Qur'an alKarim terbilang kuat. Sebab penganggaran pengelolaan pendidikan secara mandiri disuplai oleh yayasan pusat. Sementara yayasan pusat memiliki donatur anggaran yang kuat dan terkelola secara profesional.

Ketiga, profesionalitas SDM. Seluruh pendidik sudah berkualifikasi pendidikan S1 bidang pendidikan dan berbagai bidang ilmu yang lain. Profesionalitas pendidik ini juga dibentuk melalui workshop mandiri, pelatihan, magang, serta mengikutsertakan setiap guru mengikuti seminar dan organisasi profesi seperti: Himpaudi, Ikatan Guru TK Islam (IGTKI), dan sejenisnya. Out put pengembangan profesionalitas SDM mampu menghasilkan berbagai produk nyata seperti RKM yang sudah terstandar kurikulum dua ribu tiga belas, aneka metode dan strategi pembelajaran, rumusan perencanaan pembelajaran dan sebagainya. Sehingga setiap guru dilarang keras menyampaikan materi basi dan tidak up to date disetiap proses pembelajaran berlangsung.

Keempat, memiliki pelanggan yang banyak. Kekuatan pelanggan menjadi ujung tombak sebuah lembaga pendidikan. Kekuatan ini dibentuk atas kerjasama dan kepercayaan masyarakat sekitar terhadap TK Darul Qur'an al-Karim. Selain itu, kekuatan pelanggan juga disebabkan terdapatnya ciri khas pembelajaran berbasis al-Qur'an yang sangat berbeda dengan TK lain disekitar kecamatan Baturraden. Terlebih kondisi modernisasi dan gejolak kebobrokan zaman menjadikan masyarakat lebih memilih modelmodel pendidikan berbasis al- 
Qur'an sebagai alternatif sekaligus preventif bagi perkembangan anak semenjak usia dini terhadap perilaku a moral yang berkembang pesat di masyarakat.

Kelima, kuatnya koordinasi antara guru dengan pihak yayasan dan masyarakat. Yayasan sebagai supporting kerap kali melakukan koordinasi sekaligus supervisi secara langsung dengan dewan guru dalam menjalankan kebijakan dan proses pembelajaran. Koordinasi dengan masyarakat juga menjadi aspek penting. Sebab proses pendidikan anak usia dini idealnya melibatkan kerjasama secara konsisten antara pihak sekolah, keluarga dan masyarakat.

Keenam, posisi strategis TK Darul Qur'an al-Karim berada wilayah pedesaan yang belum terkontaminasi kerusakan lingkungan dan moral sehingga terasa masih berada dalam kondisi suhu yang sangat sejuk. Terlebih TK Darul Qur'an al-Karim berdekatan dengan lokawisata Baturraden, bagian selatan dari lereng gunung Slamet.

Kekuatan di atas menjadi
faktor penentu
implementasi
peningkatan mutu
kebijakan
pendidikan berbasis al-Qur'an di TK Darul Qur'an al-Karim. Kekuatan tersebut bersifat saling melekat antara satu unsur dengan unsur yang lain. Sehingga berbagai kebijakan terealisasi secara optimal melalui proses perencanaan yang matang, komitmen semua pihak dalam melaksanakan kebijakan, supervisi dan evaluasi secara terukur melalui pelaporan secara transparan dan dapat dipertanggungjawabkan. b. Kelemahan (Weakness)

Berbagai kelemahan yang tampak pada pelaksanaan kebijakan peningkatan mutu pendidikan berbasis al-Qur'an di TK Darul Qur'an al-Karim diantaranya:

Pertama, kurang rapihnya sistem dokumentasi dan pengarsipan secara tersentralisasi. Lembaga pendidikan yang bermutu seharusnya menerapkan sistem kerapihan administrasi serta pengarsipan. Terlebih prinsip pengelolaan administrasi yang baik dilakukan melalui langkah segala bentuk kegiatan harus tercatat dan apa yang sudah tercatat harus dilakukan. Kelemahan pada poin ini tentu disebabkan oleh berbagai faktor, salah satunya SDM tenaga kependidikan kurang berpengalaman, sebatas masih mencatat terhadap apa yang diperintahkan pimpinan, sehingga berbagai kebijakan belum tercatat secara rapi dan belum terdokumentasikan.

Kedua, sistem perencanaan anggaran masih lemah, hal ini berdampak pada munculnya usulan anggaran serta kebutuhan sarana prasarana pendidikan tak terduga. Idealnya setiap awal tahun, pihak sekolah menyusun rancangan Rencana Kegiatan dan Anggaran Keluaran (RKAKL) secara sistematis sesuai dengan kebutuhan prioritas. Usulan RKAKL ini selanjutnya diajukan kepada pihak yayasan sebagai bahan untuk ditindaklanjuti ditahun berjalan atau yang akan datang.

Ketiga, mayoritas guru belum menguasai hafalan juz 30 , hal ini berdampak pada pembebanan 
tanggung jawab tunggal guru tahfidz dalam mengajarkan hafalan al-Qur'an kepada peserta didik. Keempat, lemahnya silaturrahim melalui program home visit. Kunjungan rumah sebagai agenda silaturrahim dan mensukseskan berbagai kebijakan melalui aspek penguatan dan dukungan wali siswa masih belum terealisasi secara optimal. Kunjungan rumah idealnya dilakukan minimal satu pekan sekali secara bergilir yang dilakukan guru guna melihat dukungan dan peran orang tua dalam mensukseskan kebijakan peningkatan mutu pendidikan. Tanpa peran dan dukungan masyarakat (wali siswa), kebijakan apapun mustahil terealisasi secara sempurna.

Kelima, tidak adanya standar input kemampuan peserta didik. Hal ini berakibat tidak seragamnya tingkat kemampuan hafalan setiap peserta didik. Produk kebijakan dalam bidang tahfidz al-Qur'an akhirnya tidak mencapai hasil secara maksimal. Idealnya pihak sekolah menerapkan sistem evaluasi ujian masuk khususnya dalam bidang kemampuan hafalan. Tujuan dari sistem evaluasi awal ini dimaksudkan agar tercipta keseragaman kemampuan minimal setiap peserta didik guna mencapai target yang telah ditentukan dalam rumusan kebijakan.

Keenam, belum memiliki laboratorium pendidikan berbasis al-Qur'an. Laboratorium ini selain berfungsi sebagai media eksperimen juga menjadi rujukan bagi TK yang lain.

\section{c. Peluang (Opportunities)}

Beberapa peluang yang dapat dirumuskan dalam pelaksanaan kebijakan peningkatan mutu berbasis al-Qur'an di TK Darul Qur'an al-Karim diantaranya:

Pertama, religiusitas keIslaman serta minat masyarakat terhadap model pendidikan anak usia dini berbasis al-Qur'an mengalami perkembangan pesat di masyarakat. Secara realitas, masyarakat Banyumas kini lebih merindukan model pendidikan yang menekankan sentuhan spiritual dibandingkan model pendidikan yang menekankan aspek intelektual. Lahirnya lembaga pendidikan Islam terpadu dengan ciri khas tahfidzul Qur'an dari tingkat TK hingga SMA diwilayah kabupaten Banyumas menjadi incaran masyarakat secara umum tanpa melihat sisi pembiayaan yang cukup mahal.

Kedua, dukungan dinas pendidikan terhadap rekomendasi kampung tahfidz. Perihal ini berpeluang untuk dilakukan kerjasama dengan berbagai pihak guna mendapatkan bantuan dalam mencetak anak-anak penghafal alQur'an. Ketiga, anak-anak penghafal al-Qur'an menjadi duta tahfidz sekaligus menjadi tamu kerajaan Saudi Arabia untuk menunaikan ibadah haji yang biayanya ditanggung oleh pihak kerajaan. Keempat, program tahfidzul Qur'an mengantarkan anak-anak berpeluang mendapatkan beasiswa pendidikan secara total dari pemerintah dalam negeri ataupun luar negeri. Sehingga orientasi masyarakat masih menganggap lembaga pendidikan berbasis al-Qur'an menjadi pilihan tepat dalam mengantarkan anak-anaknya menggapai kesuksesan. Kelima, belum lahir pesaing TK negeri 
ataupun swasta berbasis al-Qur'an di wilayah Baturraden. Kondisi ini menjadi peluang empuk dalam mengembangkan lembaga secara profesional.

\section{d. Ancaman (Threats)}

Beberapa ancaman yang
dimungkinkan muncul dalam
merealisasikan program kebijakan
peningkatan mutu pendidikan
berbasis al-Qur'an di TK Darul
Qur'an al-Karim diantaranya:
pertama, sangat dimungkinkannya
donatur tetap yayasan sebagai
penopang biaya operasional TK
bubar. Bubarnya donatur terjadi
atas berbagai faktor seperti:
meninggal dunia, memasuki masa
pensiun dan sebagainya. Perihal ini
perlu diantisipasi sedini mungkin
melalui strategi seperti: TK perlu
memiliki badan usaha yang
menguntungkan, TK memiliki
rekanan kerjasama dalam bidang
atau spesialisasi tertentu, memiliki
jaringan lintas negara dan
sebagainya.

Kedua, munculnya pandangan masyarakat terhadap TK Darul Qur'an al-Karim sebagai sebuah lembaga pendidikan di bawah asuhan gerakan Syi'ah. Perihal ini perlu ada pelurusan anggapan bahwa TK Darul Qur'an al-Karim berada di bawah yayasan Darul Qur'an al-Karim bermadzhab suni. Pelurusan anggapan perlu segera dilakukan agar masyarakat tetap percaya dalam menitipkan putraputrinya menempuh pendidikan di TK Darul Qur'an al-Karim. Strategi lain diantaranya: TK mengadakan forum silaturahmi, diskusi non formal serta kerjasama dalam berbagai hal dengan TK lain di bawah kelembagaan ormas islam, mengadakan pertukaran guru, pertukaran supervisi pembelajaran, menerbitkan publikasi ilmiah dan riset pada isuisu seputar pendidikan anak usia dini perspektif al-Qur'an dan sunnah.

Ketiga, adanya komunitas penyebar berita hoax dan hacker yang sengaja disusun oleh sekelompok komunitas untuk meruntuhkan citra yayasan Darul Qur'an al-Karim. Strategi yang dapat dilakukan dalam mengantisipasi munculnya ancaman tersebut diantaranya meningkatkan kapasitas atau kemampuan tenaga kependidikan sebagai programmer guna melakukan pengamanan terhadap website yayasan.

\section{SIMPULAN}

Kebijakan peningkatan mutu berbasis al-Qur'an di TK Darul Qur'an al-Karim secara konkret sudah terealisasi ke dalam tujuh kebijakan. Kebijakan tersebut semata-mata bertujuan mensukseskan visi lembaga untuk menjadi pusat pendidikan anak usia dini berbasis al-Qur'an terdepan di wilayah Barlingmascakeb. Selain itu, setiap kebijakan memiliki tujuan serta indikator secara jelas dan terukur. Perihal tersebut dapat dicapai melalui perencanaan secara matang, adanya komitmen, kerjasama serta memperkuat koordinasi dari seluruh unsur terkait yang terbentuk dalam proses pertemuan rutin setiap akhir pekan dan akhir bulan.

$\begin{array}{lcr}\text { Kebijakan } & \begin{array}{r}\text { yang } \\ \text { pada }\end{array} & \begin{array}{r}\text { telah } \\ \text { akhirnya }\end{array} \\ \text { direncanakan } & \text { penetapan } & \text { agenda } \\ \text { melahirkan } & \text { pendiakan } \\ \text { kebijakan secara tertulis, } & \text { kemudian } \\ \text { kebijakan } & \text { tersebut } & \text { mulai } \\ \text { diimplementasikan secara } & \text { terstruktur }\end{array}$


SAFRUDIN AZIZ, KEBIJAKAN PENINGKATAN MUTU PENDIDIKAN BERBASIS AL-QUR'AN DI TK DARUL QUR'AN AL-KARIM KARANGTENGAH BATURRADEN BANYUMAS TAHUN 2016-2017. Early Childhood Vol. 1 No. 2, november 2017

dan bertahap dengan melihat situasi dan kondisi yang ada. Pencapaian realisasi kebijakan diukur melalui evaluasi baik secara kualitatif maupun kuantitatif guna melihat seberapa besar keberhasilan yang telah dicapai dalam mengimplementasikan kebijakan tersebut. Setelah dilakukan proses analisis, terdapat ancaman yang perlu dicari alternatif solusi dan pemecahannya. Solusi tersebut dilakukan melalui strategi secara tepat serta berprinsip menjunjung tinggi nilai-nilai harmonisasi perbedaan yang ada. 
DAFTAR PUSTAKA

Al-Hafidz. Pedoman Dauroh alQur'an. Jakarta: Dzilal Press, 1995.

Anderson, James E. Public Policy Making. New York: Holt, Renehart and Winston, 1979.

Arikunto, Suharsimi. Prosedur Penelitian Suatu Pendekatan Praktik. Jakarta: PT Rineka Cipta, 2014.

Arismantoro. Tinjauan Berbagai Aspek Character Building: Bagaimana Mendidik Anak Berkarakter. Yogyakarta: Tiara Wacana, 2008.

Bobby Herwibowo Lc Penemu Metode Master, https://thehappytraining.wordpre ss.com/2015/10/03/ustad-bobbyherwibowo-penemu-metodemaster. Accessed: 21 Oktober 2017.

Departemen Pendidikan dan Kebudayaan. Kamus Besar Bahasa Indonesia. Jakarta: Balai Pustaka, 2005.

Djohar. Analisis Kebijakan Pendidikan: Diktat. Yogyakarta: Pps UIN Sunan Kalijaga, 2008.

Dokumentasi RKM TK Darul Qur'an al-Karim Karangtengah Baturraden Banyumas tahun 2017.

Dokumentasi Visi dan Misi TK Darul Qur'an al-Karim Karangtengah Baturraden Banyumas tahun 2017.

Dunn, William N. Public Policy Analysis: an Introduction. New Jersey: Englewood Clifs, 1994.

Echols, John M. dan Shadily, Hassan. Kamus Inggris Indonesia. Jakarta: Gramedia Pustaka Utama, 2005.
Hornby, AS. Oxford Advanced Learner's Dictionary of Current English. New York: Oxford University Press, 2010.

Howlet, Michael and Ramesh, M. Studying Public Policy: Policy Cycles and Policy Subsystems. Toronto: Oxford University Press, tt.

Munawwir, Ahmad Warson. Kamus Al-Munawwir: Kamus ArabIndonesia Terlengkap. Surabaya: Pustaka Progresif, 1997.

Na'imah, Khotimatun. Coparenting pada Keluarga Muslim. Indigenous, Jurnal Ilmiah Berkala Psikologi Vol. 11, No. 1, Mei 2009.

Sugiyono. 2013. Metode Penelitian Pendidikan. Bandung: Alfabeta, 2013.

Tjiptono, Fandy dan Diana, Anastasia. Total Quality Management. Yogyakarta: Andi, 2003.

Wawancara dengan Kepala TK Darul Qur'an al-Karim Karangtengah Baturraden, 21 Oktober 2017. 